\title{
Out of Asia, or How we can Fight Dogmatism
}

\author{
Marcel Otte* \\ Prehistory Department, University of Liege, Belgium
}

Submission: August 13, 2018; Published: August 22, 2018

*Corresponding author: Marcel Otte, Prehistory Department, University of Liege, 7, place du XX août, Bldg. A1, 4000 Liège, Belgium, Tel: 32/4366-5476; Email: marcel.otte@ulg.ac.be

Keywords: Dogmatism; Human Societies; Sapiens; Doksa; Ideology; Racism; Epistemology; Anthropology; Philosophers; Biologists; Nationalism; Script; Articulation; Pre-History; Humankind; Archaeologists

\section{Opinion}

Human societies counter the plight of the absurd by creating systems of beliefs: they need faith! In the West, religions have only recently been replaced by sciences which, along with their new answers, carry their load of new dogmatism. They generate truths just as religions have always done, no more, since they too are human. If the pleasure of knowledge and intelligence are part of what delights us today, it also has adverse consequences: science must be accepted at face value by outsiders, just as happens for religious belief. Now nobody knows what part is played by ideology in scientific publications, but it must be significant since they depend on subsidies, which in turn determine which way the findings must go. To be acknowledged and be granted subsidies, researchers must comply with the doksa: this is the rub! Copernican or Galilean revolutions are as rare and dangerous as those that set the history of civilisations upside down, be it in France or in Russia.

As soon as we touch upon human prehistory, the danger is even more serious: our findings define our own nature and vindicate our lot in view of our origins! All literature on prehistory is pervaded by such summary and biased ideological trends. And whiffs of nationalism stench even worse: people do not believe the thing in England, Russia, China or France. For we cannot escape our own definition of humankind: it is the bed rock on which daily and high political actions rest. For instance, to counter race segregation in the US, modern humans had to come from Africa, without any documented evidence other than peer reviewed journals. Obviously in this imaginary script, those humans could only be sapiens, i.e. like us: most civilized! Other species would have been swiped away by this new and prestigious species. On the contrary however we have plenty of evidence showing that humans who lived before and alongside sapiens mastered refined skills. Racism has thus shifted from far away in space to far away in time: Neanderthal people were not really like us. And all modern humans had either to come from Africa or still be there. This is no sense.

Cultural and cognitive skills can be found in all forms of humankind in the present and in the past. They proceed along autonomous lines of development that have their starting point in the capacity to stand and walk on your hind legs, then for millions of years skills evolved along lines specific to each species. If we look at humankind through this lens, it displays an amazing consistency from the start, and migrations only occurred within the same species. It is thus pointless to try and find the origins of modern humans outside Eurasia: they had been there for at least hundreds of millennia. The heavy and repetitive insistence of some colleagues on a universal African origin is evidence of a dogmatic position: they overdo it, they are scared, and they want to comfort themselves and each other. We are aware that Neanderthal humans were different from modern humans, indeed they had been separated for hundreds of millennia: what can DNA testing add to this evidence? But we also know that any DNA testing must result in those findings, long before it has even started. Studies just denied that relations with modern fossils were Asian and not African: it was not part of the desired outcome, so it was conveniently forgotten.

Yet all cultural studies have consistently shown that in the upper Stone Age Eurasia was one continent. There is no evidence of those traditions on the huge African continent: this is crystal clear. But a dogmatic is much stronger than observations based on historical behaviour. This results from hierarchies, first among sciences (biology against anthropology), then among ideologies (US vs Asian). Beyond this accumulation of repeated errors, intoxication through the media and the confusion brought into the minds of young people, such wilful blindness against reason and basic evidence introduces a heavy bias. It uses prehistory to support simplifying caricature that ought to 
cover in shame serious archaeologists, who are hardly prepared for technical jousting. The sneering and shrugging between 'hard liners' and 'soft liners' at conferences must be met with the quiet determination of a powerfully argument epistemology: this is what we are responsible for.

Such imperialist dogmatism takes on perverse and surrealist proportions when it reduces humankind to the way climate would affect anatomy, or migrations. We all know that peoples decide for themselves, but we prefer not to know when we discuss people who lived before us, since they must be perceived as inferior. Neanderthal people are denied the right to bury their dead, to practice rituals, to play musical instruments. They are said to have been collectively wiped out because of disastrous climate changes. External causes are adduced to account for a mode of thinking that had to be somehow deficient, as is often implied about formed colonized people. The one difference is that the latter are still (precariously) extent whereas Palaeolithic people are not. An insidious racist connotation has been added to intellectual paucity.

Prehistory must develop on its own, particularly with respect to natural sciences such as biology. It is a historical science that studies the development of civilizations inscribed on deep-lying, consistent and meaningful universal trends. Analogies that occur everywhere between sequences of inventions and of spiritual breakthroughs are evidence enough for specific phenomena in human thinking as organized in collective networks. Those analogies still must be interpreted but they resist any a priori reduction, based either on an ideological bias or on concomitant disciplines. Science is indeed the referential axis of our current values. But it must be fed with the emotional components on which intelligence is built. Prehistory stands at this very articulation: giving meaning to what moves, seduces, fascinates us. Once it has been acknowledged in its specificity, this field of intellectual activities demands that its own laws be respected, without attempting to reduce it to any other. Exploring the foundations of humankind cannot be carried out by external amateurs, whether writers, philosophers or biologists who would follow their own reductive line of approach. We must take on the task of probing the way those societies functioned, the breakthroughs they had achieved, their objectives and longterm consequences. What is at stake is too serious to be left to ravings that are external to our discipline. It is our responsibility towards the definition of our nature, our skills and our future.

\section{Your next submission with Juniper Publishers will reach you the below assets}

- Quality Editorial service

- Swift Peer Review

- Reprints availability

- E-prints Service

- Manuscript Podcast for convenient understanding

- Global attainment for your research

- Manuscript accessibility in different formats

( Pdf, E-pub, Full Text, Audio)

- Unceasing customer service

Track the below URL for one-step submission https://juniperpublishers.com/online-submission.php 